\title{
Applied Human Development: Domain Guest Editors
}

\author{
Joyce Walker, $P h D$
}

Joyce A. Walker, PhD, professor emeritus at the University of Minnesota Extension Center for Youth Development. A founding faculty member with the youth development leadership master's of education program in the College of Education \& Human Development, she has given leadership to graduate level youth worker education throughout Minnesota. She has served as director of the Youth Work Institute offering non-credit training and professional development courses online and on site for youth workers in communities across the state and nation. Joyce is active on community boards, has served as national co-chair of the Next Generation Youth Work Coalition, and serves on the editorial board of the U.K. journalYouth \& Policy.

\section{Dale Blyth, $P h D$}

Dale Blyth provides leadership for the Youth Work Institute, a joint venture of the University of Minnesota Extension Center for Youth Development and the College of Education and Human Development. These efforts are focused on making a measurable difference in the quality, availability, and impact of nonformal community learning opportunities for Minnesota young people. The Youth Work Institute reaches more than 4000 youth workers with exceptional non-credit educational experiences, and applied research and evaluation efforts that bridge research, practice, programs, policy, and public understanding. He also uses his diverse background in university, non-profit, and policy work to help build the field of youth development. He is currently examining new pathways to improve the impact of youth programs through aligning different types of accountability, different perspectives and implications of extending learning time versus expanding learning approaches, the role of intermediary organizations in transforming community approaches to the quality, accessibility and impact of community learning opportunities, and the role of larger policy frameworks and tools for effective, long-term changes in children and youth outcomes.

In 2004-2005 Dale served as chief of staff for the university president's Minnesota Commission on Out of School Time and its report Journeys into Community: Transforming Youth Opportunities for Learning and Development. Working in collaboration with four legislative co-chairs, he helped found and support the bipartisan, bicameral Children and Youth Legislative Caucus. He is also a founding member and hosts the national Next Generation Youth Work Coalition, which is dedicated to developing the workforce of youth workers. He is a member of Minneapolis Mayor R.T. Rybak's Youth Violence Prevention Executive Committee, St. Paul Mayor Chris Coleman's 2nd Shift Commission, the Greater Twin Cities United 
Way Education Committee, the Board of Youthprise, and the Hennepin County A-GRAD Oversight Committee.

\section{Jim Anglin, $P h D$}

Jim Anglin began his career as a child and youth care worker in a mental health center in Vancouver after which he moved to Victoria and began a six-bed group home for four boys and two girls who were experiencing a variety of distresses in their lives. Following these front-line work experiences he pursued graduate studies and then spent two years in social policy work in Ottawa and two years as a senior project coordinator with the Children's Services Division in Toronto. Returning to B.C. in 1979, he joined the faculty of the School of Child and Youth Care at the University of Victoria where he is a full professor and former director.

His recent research interests have focused on a re-appreciation of residential care for youth and his latest book is titled Pain, Normality and the Struggle for Congruence: Reinterpreting Residential Care for Children and Youth (Haworth, 2002). He has published in North American journals and international texts on a variety of child and youth care issues in addition to residential care, including professionalization, quality assurance and standards, parent education and support, and international initiatives. He is on the editorial boards of the Child and Youth Care Forum, Child and Youth Services, and Reclaiming Youth at Risk. He was coordinating editor for the text Perspectives in Professional Child and Youth Care (Haworth, 1990). Over the past 20 years, he has presented papers, keynote addresses and workshops in over 40 countries. Jim currently serves as director, Office of International Affairs and Adviser to the Provost at the University of Victoria.

\section{Michael Nakkula, EdD}

Dr. Nakkula's teaching and research focus on the development of resilience and the promotion of possibility development among low-income children and youth. He is particularly interested in the integration of counseling, mentoring, and educational processes in urban schools to create contexts that allow students to thrive in school and during their transition to higher education and career opportunities. Dr. Nakkula works with many national organizations to develop applied research strategies that promote the study of developmental and educational initiatives in support of optimal youth development. 


\section{COMPETENCY IV: RELATIONSHIP AND COMMUNICATION}

We selected writings for this domain with the awareness that relationship and communication are inseparable and central to all aspects of child and youth care work. In this regard, our path was a little like traversing a Mobius strip. As we traveled through the literature we looked at a number of writings from several perspectives within this inescapable band of thought.

To begin we each selected two articles for each of the assigned categories: classic, research, and practice. Rather than think of our selections as the best or definitive writings, we searched for writings that either generated or built upon many excellent contributions on these topics. We also agreed that there are too many bests in our field for there to be a single best.

After a few weeks of discussion we selected three contributions that were on all our final lists: "Growing Together: The Personal Relationship in Child and Youth Care" by Gerry Fewster, "Rhythmicity: A Powerful Force for Experiencing Unity and Personal Connections" by Henry Maier, and "You are What You Do and Become What You've Done: The Role of Activity in the Development of Self" by Karen VanderVen. As pivotal works, their writing challenged and stretched our understanding of the foundational knowledge and competencies in the relationship and communication domain. The authors built upon prior research and experience, showed us how it could be applied in the present, and made us curious about new approaches and applications for the future.

The selection of these authors should not come as a surprise. They have been influential figures in our field for many years. Their teaching and writing have been instrumental in the development of curriculum and in one way or another all of the domains in the certification process. Each one, Henry, Gerry, and Karen, is noted for numerous contributions to the child and youth care literature, and widely respected and admired as forward thinkers. Our work has been enriched by their friendship, spirit, creativity, and intelligence. Their teachings serve as models for us all.

As instructed by the editors, we attempted to categorize their work as classic, research, or practice, but we could not find a way to squeeze any of them into one category. Each contribution could be considered a classic and each exemplifies good research and best practice. As the competent practitioners and researchers, these writers observed, lived, critiqued, compared, analyzed, interpreted, and described what they experienced in their professional work and study of work with young people and those who work with them. Their conclusions were based on prior experience, literature reviews, and applied or scientific research. All three readings remain as relevant today as when they were written. Often referenced by others, their works are a vital part of the growing discourse that advances our collective understanding of child and youth care. At this point in our evolution, they are, in essence, truly foundational works. They are shoulders on which others may stand. 
A central theme to these writings, it is the dynamic nonlinearity of relationships and communication between and among children and youth and workers as experienced in multiple contexts and activities. The writers ask us to think about how the concepts are applied with youth in the moment or activity, relating, doing, experiencing, learning, and being together as we move within and across systems, self, and personal spaces.

These papers overlap into many of the other competencies in the "Competencies for Professional Child and Youth Work Practitioners" document. In this regard the contributions are consistent with the framework in Appendix A of the document, which speaks to the need for an integrative approach. In child and youth work praxis, competencies such as listening do not occur in isolation from place, activity, self-awareness, developmental interactions, ethics, etc. For professional workers who seek to interact with young people with attentiveness and authenticity, the writers remind us that being and doing are inseparable.

The ability to foster, form, model, and nurture healthy relationships defines characteristics of those who choose to be with youth in developmentally positive ways. Unfortunately, the numerous duties and activities that comprise child and youth care can at times obscure the absolute centrality of relationship and communication to our work. Thus, we must come home to this centrality time and time again. It is, after all, what drew us to this way of being with and for young people in the first place.

In conclusion, our selections helped us see and feel relationship and communication, concretely and theoretically, which invited us to participate in dialogue and reflection. And we chose to do so. Now it is your turn to decide if you want to join in.

\section{Relationship and Communication Domain Editors}

Mark Krueger, $P h D$

Youth Work Learning Center, University of Wisconsin-Milwaukee

Claire King, EdD

Hudson Catholic Regional High School

Thom Garfat, $P h D$

TransformAction Consulting and Training

\section{References}

Fewster, G. (1990) Growing together: The personal relationship in child and youth care. In J. Aglin, C. Denholm, R. Furguson, \& A. Pence, (Eds.), Perspectives in professional child and youth care. New York: Haworth. 
Maier, H. (1992). Rhythmicity: A powerful force for experiencing unity and personal connections. Journal of Child and Youth Care Work, 8, 7-13.

VanderVen, K. (1999). You are what you do and become what you've done: The role of activity in the development of self. Journal of Child and Youth Care, 13, 133-148. 